\title{
KEMAMPUAN BERPIKIR KRITIS SISWA DALAM MENYELESAIKAN SOAL JUMPING TASK PADA MATERI PERBANDINGAN BERDASARKAN GENDER
}

\author{
Anggraini Dwi Ikhwani ${ }^{1}$, Hobri ${ }^{2}$, Ervin Oktavianingtyas ${ }^{2}$ \\ Program Studi Pendidikan Matematika, FKIP, Universitas Jember \\ Jalan Kalimantan 37 Kampus Tegalboto Jember 68121 \\ E-mail: aaini130@gmail.com
}

\begin{abstract}
This study aims to describe the critical thinking ability of male and female students in solving jumping task problems on proportion. The jumping task question used is a question with level C4 in Taksonomi Bloom. This type of research used is descriptive research with a qualitative approach. The data collection method used consisted of the documentation mathematics students report in the first semester, critical thinking test, and interviews. The subjects used in this study are 32 students of class VII G on SMPN 4 Jember. consists of 16 male students and 16 female students. The students are divided into three groups based on the mathematics students report in the first semester. The groups are high, medium, and low category mathematics ability. The results showed that male students with high category mathematics ability had TKBK 3 (critical), male students with medium category mathematics ability had TKBK 1 (less critical), male students with low category mathematics ability had TKBK $O$ (not critical). While female students with high category mathematics ability had TKBK 3 (critical), female students with medium category mathematics ability had TKBK 2 (quite critical), female students with low category mathematics ability had TKBK 1 (less critical).
\end{abstract}

Keyword : Critical Thinking, Gender, Jumping Task, Proportion

\section{PENDAHULUAN}

Kemampuan berpikir kritis merupakan salah satu tujuan dari pembelajaran matematika. Hal ini sesuai dengan yang tercantum pada Peraturan Menteri Pendidikan dan Kebudayaan Nomor 23 Tahun 2006 mengenai Standart Kompetensi Lulusan Kurikulum Tingkat Satuan Pendidikan yang didalamnya tertera bahwa tujuan dari pembelajaran matematika adalah siswa mempunyai kemampuan logis, analitis, sistematis, kritis, dan kreatif serta memiliki kemampuan kerja sama. Kemampuan berpikir kritis adalah kemampuan yang dimiliki seseorang untuk menggunakan dan mengembangkan kemampuan yang dimilikinya sehingga mampu memecahkan masalah yang sedang dihadapi, serta mampu menganalisis dan mengevaluasi informasi secara tepat, cermat, dan teliti tanpa menimbulkan pemahaman yang berbeda dalam usaha menyelesaikan masalah yang berhubungan dengan kehidupan nyata serta dapat mengatasi kesalahan dan kekurangan yang sedang dihadapi [1]. Kemampuan berpikir kritis siswa dapat dikembangkan melalui proses pembelajaran [2]. Proses pembelajaran matematika dapat dilakukan dengan melakukan kegiatan mengajar. Mengajar dapat dilakukan dengan berbagai cara penyampaian atau metode, salah satunya dengan pemberian soal-soal tingkat tinggi. Salah satu soal yang bisa diberikan yaitu dengan memberikan soal jumping

\footnotetext{
${ }^{1}$ Mahasiswa S1 Prodi Pendidikan Matematika FKIP Universitas Jember.

${ }^{2}$ Dosen Prodi Pendidikan Matematika FKIP Universitas Jember.
} 
task. Jumping task adalah pemberian tugas atau soal yang menantang atau berada di atas tingkatan tuntutan kurikulum [3] dan [4]. Selain itu, jumping task juga dapat diartikan sebagai soal berupa level aplikasi atau lebih berkembang [5]. Diharapkan melalui soal jumping task siswa dapat lebih tertantang untuk belajar lebih baik [6].

Gender merupakan sikap atau perilaku yang melekat pada laki-laki dan perempuan. Adanya perbedaan antara laki-laki dengan perempuan, secara umum laki-laki lebih unggul dalam bidang matematika karena kemampuan spasialnya yang lebih baik, pada umumnya perhatian laki-laki tertuju pada hal-hal yang berbau intelektual, abstrak, dan objektif, sedangkan perempuan lebih unggul dalam bidang bahasa dan menulis, pada umumnya perhatian perempuan tertuju pada hal-hal yang berbau konkrit, praktis, emosional, dan personal [7]. Perbedaan laki-laki dan perempuan terlihat pada sifat sekunder, emosional, dan aktivitas fungsi psikologis. Sifat sekunder pada perempuan terlihat pada perasaan, tidak terlihat pada pengetahuan, sehingga nilai perasaan dan pengalaman perempuan lebih memengaruhi kepribadiannya daripada perasaan laki-laki. Respon kerja dari perempuan lebih kuat dan emosional daripada laki-laki, tetapi perempuan lebih akurat dan detail [8].

Setiap orang memiliki tingkat berpikir kritis yang berbeda-beda. Tingkat berpikir kritis merupakan tingkatan masing-masing siswa dalam berpikir kritis. Richard Paul dan Linda Elder merupakan pakar berpikir kritis dalam tradisi filosofis yang menyusun suatu model berpikir kritis dengan nama populer yaitu Model Berpikir Kritis Paul dan Elder. Komponen berpikir kritis menurut Paul dan Elder ada 3 macam yaitu 1) elemen bernalar; 2) standar intelektual bernalar dan 3) karakter intelektual bernalar [9].

Penjenjangan Tingkat Kemampuan Berpikir Kritis (TKBK) berdasarkan Model Berpikir Kritis Paul dan Elder dijenjangkan menjadi 4 tingkatan [10]. Pengelompokan tingkatan tersebut berdasarkan pada 2 komponen yaitu elemen bernalar dan standar intelektual bernalar berdasarkan model berpikir kritis Paul dan Elder. Empat tingkatan tersebut adalah Tingkat Kemampuan Berpikir Kritis 3 (TKBK 3) yang berarti kritis, Tingkat Kemampuan Berpikir Kritis 2 (TKBK 2) yang berarti cukup kritis, Tingkat Kemampuan Berpikir Kritis 1 (TKBK 1) yang berarti kurang kritis dan Tingkat Kemampuan Berpikir Kritis 0 (TKBK 0) yang berarti tidak kritis. Peneliti pada penelitian ini menambahkan 1 tingkatan TKBK sehingga terdapat 5 tingkatan yaitu dengan menambahkan TKBK 4 yang berarti sangat kritis. TKBK 4 tercapai apabila semua elemen bernalar dan standar intelektual bernalar terpenuhi. Perbedaan dalam penelitian ini dengan penelitian yang lain adalah soal yang digunakan merupakan soal jumping task khususnya pada materi perbandingan, dimana soal jumping task materi perbandingan masih belum ada yang menggunakan pada penelitian-penelitian sebelumnya, sehingga tujuan penelitian ini adalah untuk mendeskripsikan kemampuan berpikir kritis siswa dalam menyelesaikan soal jumping task pada materi perbandingan berdasarkan gender

\section{METODE PENELITIAN}

Jenis penelitian yang digunakan pada penelitian ini adalah penelitian deskriptif dengan pendekatan kualitatif. Penelitian ini dilaksanakan di SMPN 4 Jember. Metode analisis data yang digunakan adalah deskriptif kualitatif dengan pengumpulan data yaitu melalui dokumentasi nilai rapor siswa semester ganjil, tes kemampuan berpikir kritis siswa, dan wawancara. Subjek penelitian dalam penelitian ini adalah siswa kelas VIIG SMP Negeri 4 Jember tahun ajaran 2019/2020 yang sedang menerima materi perbandingan. Penentuan subjek wawancara menggunakan teknik purposive sampling. Purposive sampling yaitu teknik pengambilan sampel sumber data dengan pertimbangan tertentu [11]. Pertimbangan yang digunakan pada penelitian ini berdasarkan kemampuan 
awal matematika yang dimiliki siswa. Kemampuan awal matematika dilihat dari nilai rapor matematika siswa semester ganjil yang dikelompokkan menjadi 3 kelompok yaitu siswa berkemampuan awal matematika kategori tinggi, sedang, dan rendah. Subjek wawancara pada penelitian ini ada 6 siswa yaitu 1 siswa laki-laki dan 1 siswa perempuan dengan nilai tertinggi pada setiap kelompok kemampuan awal matematika kategori tinggi, sedang, dan rendah, sehingga terdapat 3 siswa laki-laki dan 3 siswa perempuan. Terdapat 2 komponen dari Model Berpikir Kritis Paul dan Elder yang digunakan pada penelitian ini yaitu elemen bernalar dan standar intelektual bernalar dengan 11 indikator [12]. Indikator tersebut yang digunakan pada penelitian ini yang dapat dilihat pada Tabel 1.

Tabel 1. Indikator berpikir kritis

\begin{tabular}{|l|l|c|l|}
\hline \multicolumn{1}{|c|}{$\begin{array}{c}\text { Elemen } \\
\text { Bernalar }\end{array}$} & \multicolumn{1}{|c|}{ SIB } & Kode & \multicolumn{1}{|c|}{ Indikator Berpikir Kritis } \\
\hline Informasi & Jelas & $\mathrm{I}_{1}$ & Menuliskan apa yang diketahui dari soal \\
\cline { 2 - 5 } & Tepat & $\mathrm{I}_{2}$ & Menuliskan apa yang ditanya dari soal \\
\cline { 2 - 5 } & Teliti & $\mathrm{I}_{3}$ & $\begin{array}{l}\text { Menuliskan informasi yang dibutuhkan tetapi tidak } \\
\text { terdapat pada soal }\end{array}$ \\
\cline { 2 - 5 } & Relevan & $\mathrm{I}_{4}$ & $\begin{array}{l}\text { Menuliskan informasi/data yang terkait dengan } \\
\text { penyelesaian soal }\end{array}$ \\
\hline \multirow{3}{*}{$\begin{array}{l}\text { Konsep dan } \\
\text { Ide }\end{array}$} & Jelas & $\mathrm{I}_{5}$ & Menuliskan rumus untuk penyelesaian soal \\
\cline { 2 - 5 } & Tepat & $\mathrm{I}_{6}$ & Menuliskan tahap demi tahap penyelesaian soal \\
\cline { 2 - 5 } & Relevan & $\mathrm{I}_{7}$ & $\begin{array}{l}\text { Menggunakan infomasi dan konsep yang sesuai } \\
\text { dengan soal }\end{array}$ \\
\cline { 2 - 5 } & Dalam & $\mathrm{I}_{8}$ & $\begin{array}{l}\text { Menyelesaikan soal dengan alternatif jawaban yang } \\
\text { benar }\end{array}$ \\
\cline { 2 - 5 } & Jelas & $\mathrm{I}_{9}$ & $\begin{array}{l}\text { Menuliskan kesimpulan untuk } \\
\text { permasalahan dengan benar }\end{array}$ \\
\hline Sudat Pandang & Jelas & $\mathrm{I}_{10}$ & $\begin{array}{l}\text { Menuliskan kesimpulan berdasarkan konsep yang } \\
\text { benar }\end{array}$ \\
\cline { 2 - 5 } & Luas & $\mathrm{I}_{11}$ & $\begin{array}{l}\text { Menyelesaikan soal berdasarkan langkah/tahapan } \\
\text { yang benar }\end{array}$ \\
\hline
\end{tabular}

Sumber: Rahmatillah dkk. (2017)

\section{HASIL DAN PEMBAHASAN}

\section{A. Analisis Kemampuan Awal Matematika}

Berdasarkan nilai rapor matematika siswa semester ganjil, terdapat 32 siswa di dalam satu kelas. Siswa tersebut dibagi menjadi 3 kelompok kemampuan awal matematika yaitu kemampuan awal matematika kategori tinggi, sedang, dan rendah. Kelompok kemampuan awal matematika kategori tinggi terdapat 8 siswa dengan 5 siswa laki-laki dan 3 siswa perempuan. Kelompok kemampuan awal matematika kategori sedang terdapat 19 siswa dengan 9 siswa laki-laki dan 10 siswa perempuan. Kelompok kemampuan awal matematika kategori rendah terdapat 5 siswa dengan 2 siswa laki-laki dan 3 siswa perempuan. 


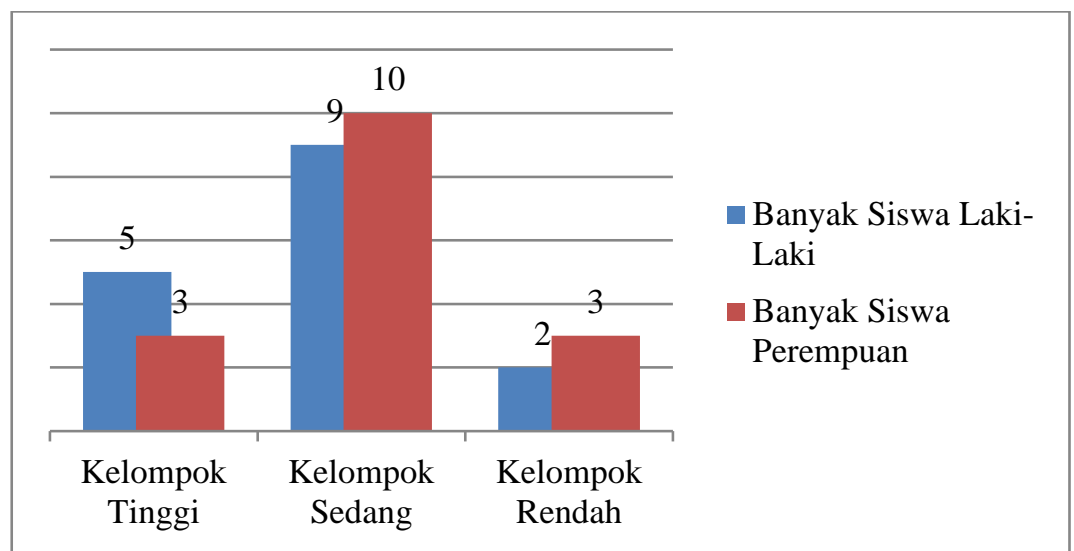

Gambar 1. Diagram pengelompokan kemampuan siswa berdasarkan nilai rapor

\section{B. Analisis Kemampuan Berpikir Kritis Siswa}

Kemampuan berpikir kritis pada penelitian ini dikelompokkan menjadi 5 tingkatan. Namun pada hasil penelitian ini hanya terdapat 4 tingkatan yang terpenuhi. Tingkatan yang tidak terpenuhi oleh subjek adalah Tingkat Kemampuan Berpikir Kritis 4 (sangat kritis). Subjek yang dibahas pada penelitian ini ada 6, untuk lebih rinci dapat dilihat pada Tabel 2.

Tabel 2. Daftar subjek penelitian

\begin{tabular}{ccc}
\hline No. & Kode Subjek & $\begin{array}{c}\text { Kelompok Kemampuan awal } \\
\text { matematika kategori }\end{array}$ \\
\hline 1. & $\mathrm{MS}_{1}$ & Tinggi \\
\hline 2. & $\mathrm{MS}_{2}$ & Sedang \\
\hline 3. & $\mathrm{MS}_{3}$ & Rendah \\
\hline 4. & $\mathrm{FS}_{4}$ & Tinggi \\
\hline 5. & $\mathrm{FS}_{5}$ & Sedang \\
\hline 6. & $\mathrm{FS}_{6}$ & Rendah \\
\hline
\end{tabular}

Berdasarkan analisis hasil tes dan wawancara didapatkan hasil bahwa terdapat perbedaan kemampuan yang kurang signifikan antara siswa laki-laki dan siswa perempuan dengan kemampuan awal matematika kategori tinggi, akan tetapi jika dilihat dari kelompok kemampuan awal matematika kategori sedang dan rendah, maka akan terlihat perbedaannya. Perbedaan tersebut dapat dilihat dari tingkatan yang dicapai oleh siswa laki-laki yang berada di bawah satu tingkat dari tingkatan yang dicapai oleh siswa perempuan. Adapun untuk lebih jelasnya dapat dilihat pada Tabel 3.

Tabel 3. Hasil pengelompokan tingkat kemampuan berpikir kritis subjek

\begin{tabular}{ll|c|c|c|c|c|c|}
\hline $\begin{array}{l}\text { Elemen } \\
\text { Bernalar }\end{array}$ & $\mathrm{SIB}$ & $\mathrm{MS}_{1}$ & $\mathrm{MS}_{2}$ & $\mathrm{MS}_{3}$ & $\mathrm{FS}_{4}$ & $\mathrm{FS}_{5}$ & $\mathrm{FS}_{6}$ \\
\hline \multirow{2}{*}{ Informasi } & Jelas & $\sqrt{ }$ & $\sqrt{ }$ & - & $\sqrt{ }$ & $\sqrt{ }$ & $\sqrt{ }$ \\
\cline { 2 - 9 } & Tepat & $\sqrt{ }$ & $\sqrt{ }$ & - & $\sqrt{ }$ & $\sqrt{ }$ & $\sqrt{ }$ \\
\cline { 2 - 9 } & Teliti & $\sqrt{ }$ & $\sqrt{ }$ & - & $\sqrt{ }$ & $\sqrt{ }$ & $\sqrt{ }$ \\
\cline { 2 - 9 } & Relevan & $\sqrt{ }$ & $\sqrt{ }$ & - & $\sqrt{ }$ & $\sqrt{ }$ & $\sqrt{ }$ \\
\hline \multirow{2}{*}{ ide } & Jelas & $\sqrt{ }$ & $\sqrt{ }$ & - & $\sqrt{ }$ & $\sqrt{ }$ & $\sqrt{ }$ \\
\cline { 2 - 9 } & Tepat & $\sqrt{ }$ & - & - & $\sqrt{ }$ & $\sqrt{ }$ & - \\
\cline { 2 - 9 } & Relevan & $\sqrt{ }$ & - & - & $\sqrt{ }$ & $\sqrt{ }$ & - \\
\cline { 2 - 8 } & Dalam & - & - & - & - & - & - \\
\hline
\end{tabular}




\begin{tabular}{ll|c|c|c|c|c|c|}
\hline $\begin{array}{l}\text { Elemen } \\
\text { Bernalar }\end{array}$ & SIB & $\mathrm{MS}_{1}$ & $\mathrm{MS}_{2}$ & $\mathrm{MS}_{3}$ & $\mathrm{FS}_{4}$ & $\mathrm{FS}_{5}$ & $\mathrm{FS}_{6}$ \\
\hline Sudut Pandang & Jelas & $\sqrt{y y y y y y y}$ & - & - & $\sqrt{ }$ & - & - \\
\cline { 2 - 8 } & Luas & Terbatas & - & - & Terbatas & Terbatas & - \\
\hline $\begin{array}{c}\text { Tingkat Kemampuan } \\
\text { Berpikir Kritis }\end{array}$ & $\begin{array}{c}\text { TKBK 3 } \\
\text { (Kritis) }\end{array}$ & $\begin{array}{c}\text { TKBK 1 } \\
\text { (Kurang } \\
\text { Kritis) }\end{array}$ & $\begin{array}{c}\text { TKBK 0 } \\
\text { (Tidak } \\
\text { Kritis) }\end{array}$ & $\begin{array}{c}\text { TKBK 3 } \\
\text { (Kritis) }\end{array}$ & $\begin{array}{c}\text { TKBK 2 } \\
\text { (Cukup } \\
\text { Kritis) }\end{array}$ & $\begin{array}{c}\text { TKBK 1 } \\
\text { (Kurang } \\
\text { Kritis) }\end{array}$ \\
\hline
\end{tabular}

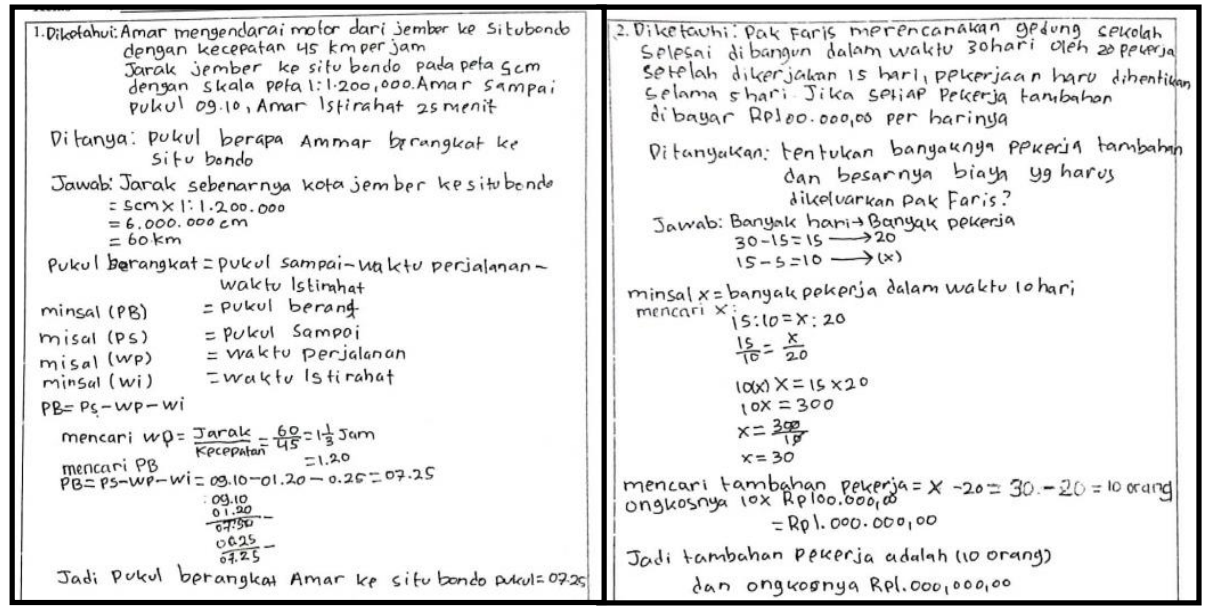

Gambar 2. Jawaban MS 1

Berdasarkan hasil tes kemampuan berpikir kritis dan wawancara yang telah dianalisis, didapatkan bahwa $\mathrm{MS}_{1}$ termasuk dalam TKBK 3 (kritis) dalam menyelesaikan soal jumping task. Hal ini juga dipengaruhi oleh kemampuan spasial yang dimiliki lakilaki. Secara umum laki-laki lebih unggul dalam bidang matematika karena kemampuan spasialnya yang lebih baik [6]. $\mathrm{MS}_{1}$ mampu menyelesaikan permasalahan hingga menemukan hasil akhir. $\mathrm{MS}_{1}$ mampu mengidentifikasi dan menyelesaikan masalah berdasarkan informasi yang jelas, tepat, teliti, dan relevan. Hal ini dapat dilihat pada langkah penyelesaian subjek. Konsep dan ide yang digunakan jelas, tepat, relevan namun tidak mendalam untuk menyelesaikan soal. Hal ini dikarenakan subjek dapat menyelesaikan permasalahan berdasarkan tahapan yang jelas dan konsep yang digunakan sesuai yaitu menggunakan konsep perbandingan senilai pada soal nomor 1 dan menggunakan konsep perbandingan berbalik nilai pada soal nomor 2 namun tidak mendalam memahami konsep perbandingan.

$\mathrm{MS}_{1}$ mampu membuat kesimpulan yang jelas dan logis. Hal ini terlihat dari hasil pengerjaan $\mathrm{MS}_{1}$ yang dapat menarik kesimpulan dari soal dengan jelas dan logis. $\mathrm{MS}_{1}$ mampu mengidentifikasi dan menyelesaikan masalah berdasarkan pada sudut pandang yang jelas namun untuk sudut pandang luas masih terbatas. Hal ini dikarenakan dalam penyelesaian $\mathrm{MS}_{1}$ hanya dapat menyelesaikan masalah dengan satu cara. Hal ini sesuai dengan teori yang mengatakan bahwa subjek dengan TKBK 3 belum mampu menggunakan alternatif atau cara penyelesaian yang lain dalam menyelesaikan soal [13]. Hal ini juga sejalan dengan teori yang menyatakan bahwa subjek yang berada pada TKBK 3 (kritis) mengerti apa yang akan dilakukan dengan standar intelektual bernalar sehingga elemen informasi dan penyimpulan dipenuhi semua standarnya, elemen konsep dan ide serta elemen sudut pandang sebagian besar standarnya juga dipenuhi [10]. 


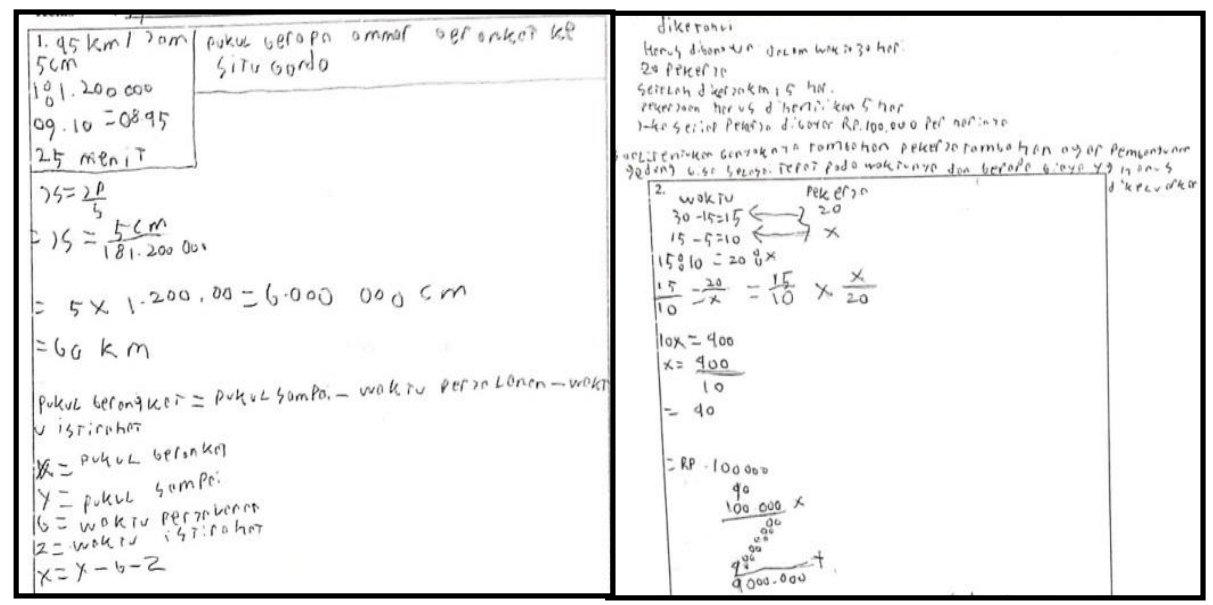

Gambar 3. Jawaban $\mathbf{M S}_{2}$

Hasil tes kemampuan berpikir kritis dan wawancara dari $\mathrm{MS}_{2}$ yang telah dianalisis, didapatkan bahwa $\mathrm{MS}_{2}$ termasuk dalam TKBK 1 (kurang kritis) dalam menyelesaikan soal jumping task. Laki-laki kurang akurat dan detail [8]. Hal ini sesuai dengan hasil pengerjaan $\mathrm{MS}_{2}$ yang kurang teliti sehingga belum mampu menyelesaikan masalah hingga menemukan hasil akhir. $\mathrm{MS}_{2}$ mampu mengidentifikasi dan menyelesaikan masalah berdasarkan informasi yang jelas, tepat, teliti, dan relevan. Hal ini dapat dilihat pada langkah penyelesaian subjek. Konsep dan ide yang digunakan jelas, namun tidak tepat, tidak relevan dan tidak mendalam. Hal ini dikarenakan subjek dalam mengerjakan permasalahan menggunakan konsep yang jelas tetapi tidak dapat menyelesaikan permasalahan berdasarkan tahapan yang benar dan konsep yang digunakan juga tidak sesuai dengan permasalahan yang dikerjakan serta tidak mendalam.

$\mathrm{MS}_{2}$ tidak mampu membuat kesimpulan yang jelas dan logis. Hal ini terlihat dari hasil pengerjaan $\mathrm{MS}_{2}$ yang tidak dapat menarik kesimpulan dari soal secara jelas dan logis. $\mathrm{MS}_{2}$ tidak mampu mengidentifikasi dan menyelesaikan masalah berdasarkan pada sudut pandang yang jelas dan luas karena $\mathrm{MS}_{2}$ tidak dapat menyelesaikan permasalahan hingga akhir dan juga belum mampu menggunakan cara lainnya. Hal ini sesuai dengan teori yang menyatakan bahwa pada tingkat TKBK 1 kemampuan berpikirnya masih terbatas yaitu menggali informasi yang memenuhi standar intelektual bernalar, menggali dan mengembangkan kesadaran akan konsep dan ide yang memenuhi standar jelas, tetapi pada saat menerapkan konsep tidak tepat, sudut pandang penyelesaian masalah tidak jelas, penalarannya juga tidak jelas dan tidak logis [10].

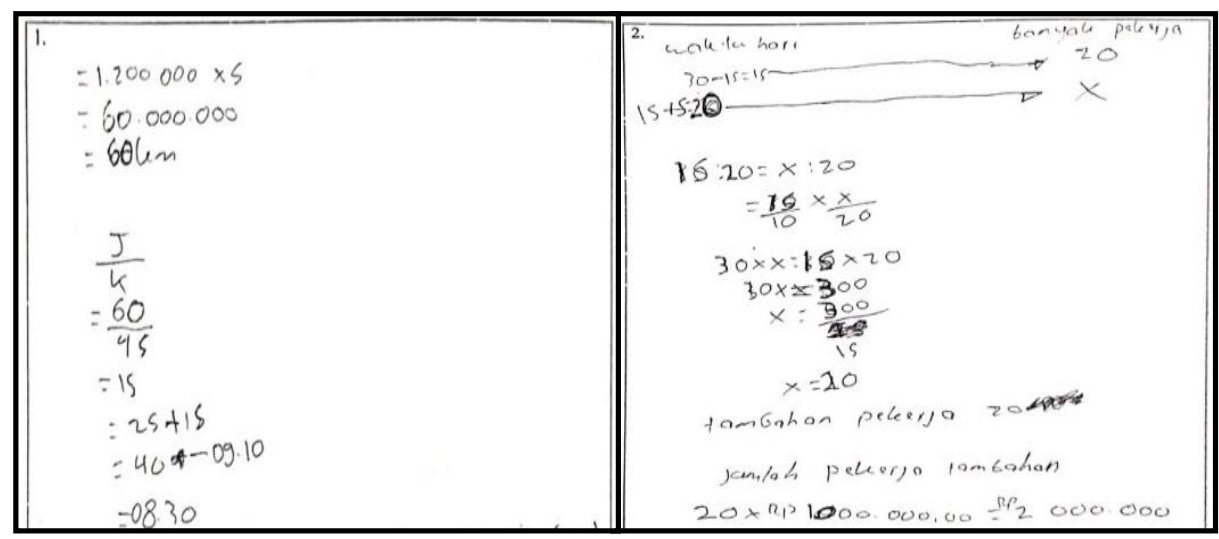

Gambar 4. Jawaban $\mathrm{MS}_{3}$ 
Kemudian untuk $\mathrm{MS}_{3}$, dari hasil tes kemampuan berpikir kritis dan wawancara yang telah dianalisis, menunjukkan bahwa $\mathrm{MS}_{3}$ belum dapat menyelesaikan permasalahan hingga menemukan hasil akhir dikarena kurang teliti. Hal ini sesuai dengan teori yang menyatakan bahwa laki-laki kurang akurat dan detail [8]. $\mathrm{MS}_{3}$ termasuk dalam TKBK 0 (tidak kritis) dalam menyelesaikan soal jumping task. Hal ini ditunjukkan dengan tidak dipenuhinya semua standar intelektual bernalar pada elemen bernalar informasi, konsep dan ide, penyimpulan dan sudut pandang. Hal ini sesuai dengan teori yang menyatakan bahwa subjek dengan tingkat tidak kritis atau TKBK 0 dalam berpikir masih belum melibatkan elemen bernalar dan standar intelektual bernalar [10]. Hal tersebut terlihat pada $\mathrm{MS}_{3}$ yang belum mampu menyelesaikan masalah hingga menemukan hasil akhir. $\mathrm{MS}_{3}$ tidak mampu mengidentifikasi dan menyelesaikan masalah berdasarkan informasi yang jelas, tepat, teliti, dan relevan. Hal ini dapat dilihat pada langkah penyelesaian subjek pada hasil tes. $\mathrm{MS}_{3}$ tidak mampu mengidentifikasi dan meyelesaikan masalah berdasarkan konsep dan ide yang jelas, tepat, relevan, dan mendalam. Hal ini dikarenakan subjek dalam mengerjakan permasalahan menggunakan konsep yang tidak jelas serta tidak dapat menyelesaikan permasalahan berdasarkan tahapan yang benar dan konsep yang digunakan juga tidak sesuai dengan konsep perbandingan senilai dan perbandingan berbalik nilai serta tidak mendalam memahami konsep perbandingan. $\mathrm{MS}_{3}$ tidak mampu membuat kesimpulan yang jelas dan logis. Hal ini terlihat dari hasil pengerjaan $\mathrm{MS}_{3}$ yang tidak dapat menuliskan dan menarik kesimpulan dari soal secara jelas dan logis. $\mathrm{MS}_{3}$ tidak mampu mengidentifikasi dan menyelesaikan masalah berdasarkan pada sudut pandang yang jelas dan luas karena $\mathrm{MS}_{3}$ tidak dapat menyelesaikan permasalahan hingga akhir dan juga belum mampu menggunakan cara lainnya.

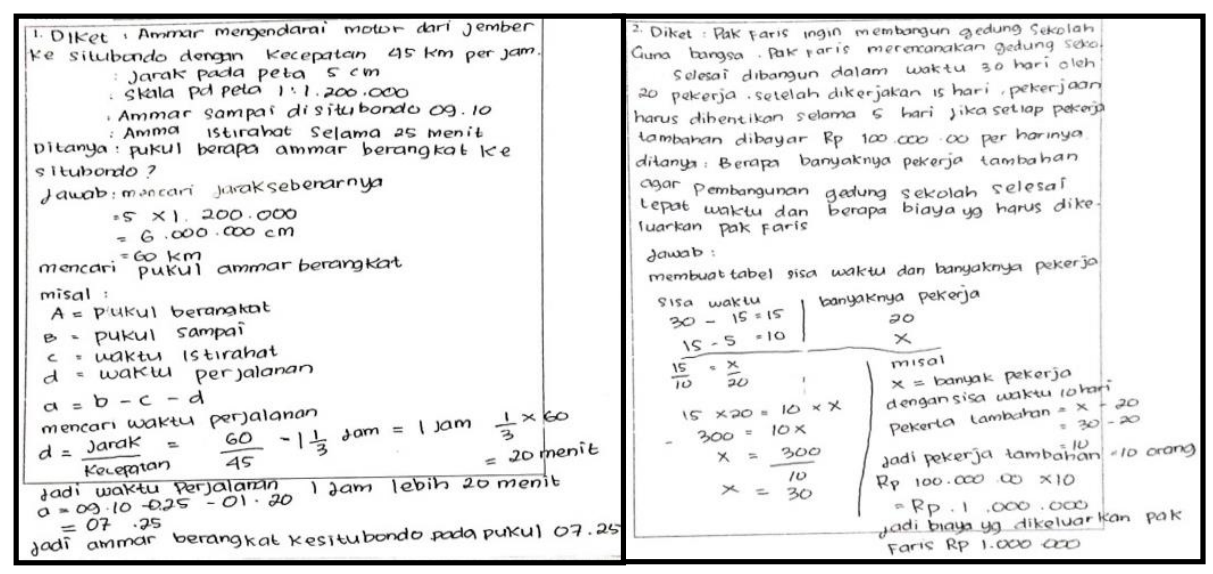

Gambar 5. Jawaban FS 4

Selanjutnya untuk hasil tes kemampuan berpikir kritis dan wawancara yang telah dianalisis dari $\mathrm{FS}_{4}$. $\mathrm{FS}_{4}$ termasuk dalam TKBK 3 (kritis) dalam menyelesaikan soal jumping task. Perempuan lebih akurat dan detail [8]. $\mathrm{FS}_{4}$ teliti dalam mengerjakan sehingga $\mathrm{FS}_{4}$ mampu menyelesaikan permasalahan hingga menemukan hasil akhir. $\mathrm{FS}_{4}$ mampu mengidentifikasi dan menyelesaikan masalah berdasarkan informasi yang jelas, tepat, teliti, dan relevan. Hal ini dapat dilihat pada langkah penyelesaian subjek pada hasil pengerjaanya. $\mathrm{FS}_{4}$ mampu mengidentifikasi dan meyelesaikan masalah berdasarkan konsep dan ide yang digunakan jelas, tepat, relevan namun tidak mendalam untuk menyelesaikan soal. Hal ini dikarenakan subjek dapat menyelesaikan permasalahan berdasarkan tahapan yang jelas dan konsep yang digunakan sesuai yaitu menggunakan konsep perbandingan senilai pada soal nomor 1 dan menggunakan konsep perbandingan 
berbalik nilai pada soal nomor 2 namun tidak mendalam memahami konsep perbandingan.

$\mathrm{FS}_{4}$ mampu membuat kesimpulan yang jelas dan logis. Hal ini terlihat dari hasil pengerjaan $\mathrm{FS}_{4}$ yang dapat menarik kesimpulan dari soal dengan jelas dan logis. $\mathrm{FS}_{4}$ mampu mengidentifikasi dan menyelesaikan masalah berdasarkan pada sudut pandang yang jelas. Adapun untuk sudut pandang luas yang digunakan untuk menyelesaikan permasalahan masih tergolong terbatas karena $\mathrm{FS}_{4}$ ganya menuliskan penyelesaian tunggal, sehingga untuk keluasan sudut pandangan masih belum tercapai. Hal ini sesuai dengan teori yang mengatakan bahwa subjek dengan TKBK 3 hanya menyelesaikan soal dengan penyelesaian tunggal [12].

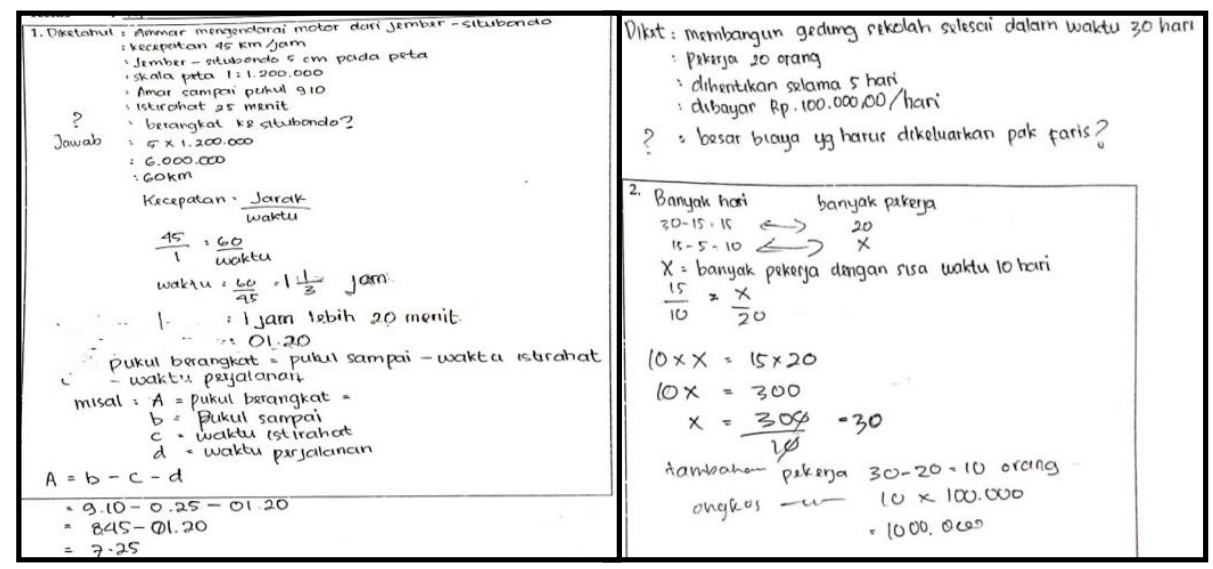

Gambar 6. Jawaban $\mathrm{FS}_{5}$

Berbeda dari $\mathrm{FS}_{4}$, hasil tes kemampuan berpikir kritis dan wawancara dari $\mathrm{FS}_{5}$ yang telah dianalisis, didapatkan bahwa $\mathrm{FS}_{5}$ termasuk dalam TKBK 2 (cukup kritis) dalam menyelesaikan soal jumping task. Hal ini dikarenakan $\mathrm{FS}_{5}$ belum dapat menyelesaikan masalah hingga menuliskan kesimpulan dari jawaban akhir. Hal ini sesuai dengan teori yang menyatakan bahwa TKBK 2 ditunjukkan dengan penalaran penyimpulan yang dilakukan masih belum memenuhi standar jelas dan logis, serta sudut pandang tidak jelas dan tidak luas [10]. Hal tersebut terlihat dari $\mathrm{FS}_{5}$ yang mampu mengidentifikasi dan menyelesaikan masalah berdasarkan informasi yang jelas, tepat, teliti, dan relevan. Hal ini dapat dilihat pada langkah penyelesaian subjek dalam mengerjakan soal perbandingan. $\mathrm{FS}_{5}$ mampu mengidentifikasi dan meyelesaikan masalah berdasarkan konsep dan ide yang digunakan jelas, tepat, relevan namun tidak mendalam. Hal ini dikarenakan subjek dapat menyelesaikan permasalahan berdasarkan tahapan yang jelas dan konsep yang digunakan sesuai yaitu menggunakan konsep perbandingan senilai pada soal nomor 1 dan menggunakan konsep perbandingan berbalik nilai pada soal nomor 2 namun tidak mendalam memahami konsep perbandingan. $\mathrm{FS}_{5}$ tidak mampu membuat kesimpulan yang jelas dan logis. Hal ini terlihat dari hasil pengerjaan $\mathrm{FS}_{5}$ yang tidak dapat menuliskan dan menarik kesimpulan dari soal secara jelas dan logis. $\mathrm{FS}_{5}$ tidak mampu mengidentifikasi dan menyelesaikan masalah berdasarkan pada sudut pandang yang jelas karena $\mathrm{FS}_{5}$ tidak dapat menyelesaikan permasalahan hingga menyimpulkan jawaban dari soal. Adapun untuk sudut pandangan keluasan juga masih belum memenuhi karena subjek hanya menggunakan satu cara dan itu belum selesai. 


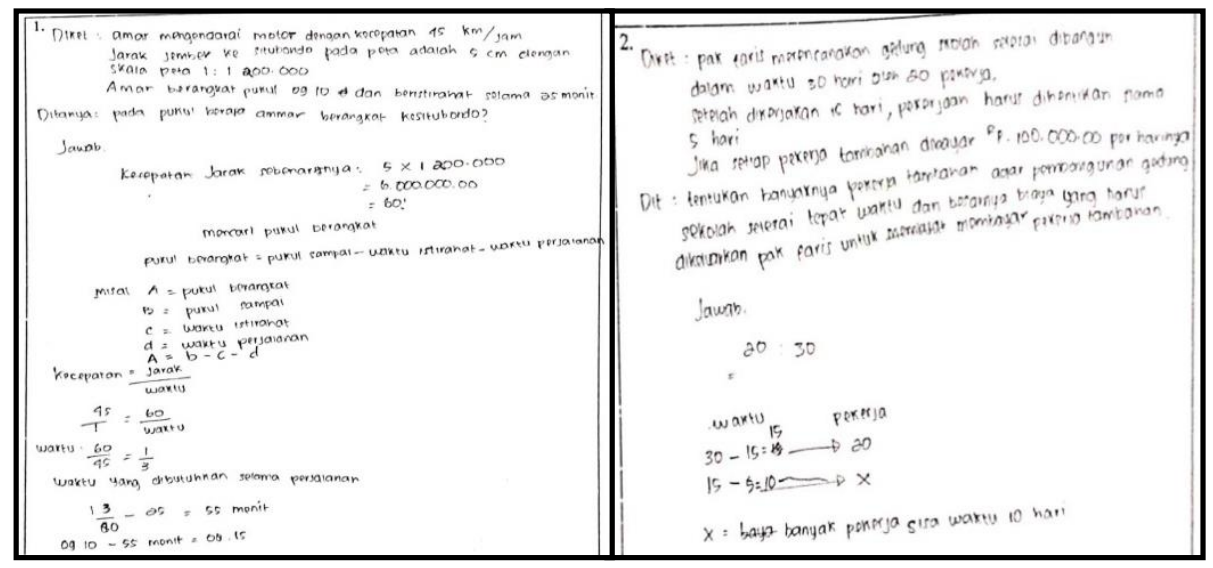

Gambar 7. Jawaban FS $_{6}$

Kemudian untuk subjek terakhir yaitu $\mathrm{FS}_{6}$, hasil tes kemampuan berpikir kritis dan wawancara yang telah dianalisis dari $\mathrm{FS}_{6}$. Menunjukkan bahwa $\mathrm{FS}_{6}$ termasuk dalam TKBK 1 (kurang kritis) dalam menyelesaikan soal jumping task. Hal ini dikarenakan FS $_{6}$ belum mampu menyelesaikan masalah hingga menemukan hasil akhir. $\mathrm{FS}_{6}$ mampu mengidentifikasi dan menyelesaikan masalah berdasarkan informasi yang jelas, tepat, teliti, dan relevan. Hal ini dapat dilihat pada langkah penyelesaian subjek dalam mengerjakan soal perbandingan. Konsep dan ide yang digunakan jelas, namun tidak tepat, tidak relevan dan tidak mendalam. Hal ini dikarenakan subjek dalam mengerjakan permasalahan menggunakan konsep yang jelas tetapi tidak dapat menyelesaikan permasalahan berdasarkan tahapan yang benar dan konsep yang digunakan juga tidak sesuai dengan konsep perbandingan senilai dan perbandingan berbalik nilai serta tidak mendalam memahami konsep perbandingan. $\mathrm{FS}_{6}$ tidak mampu membuat kesimpulan yang jelas dan logis. Hal ini terlihat dari hasil pengerjaan $\mathrm{FS}_{6}$ yang tidak dapat menuliskan dan menarik kesimpulan dari soal secara jelas dan logis. $\mathrm{FS}_{6}$ tidak mampu mengidentifikasi dan menyelesaikan masalah berdasarkan pada sudut pandang yang jelas dan luas karena $\mathrm{FS}_{6}$ tidak dapat menyelesaikan permasalahan hingga akhir dan juga belum mampu menggunakan cara lainnya.

Berdasarkan hasil analisis kemampuan berpikir kritis dengan menggunakan soal jumping task materi perbandingan, terlihat bahwa subjek siswa laki-laki maupun siswa perempuan dari kelompok kemampuan awal matematika kategori tinggi mampu mencapai TKBK 3. Hal ini sesuai dengan teori yang menyatakan bahwa tidak terdapat perbedaan yang signifikan antara kemampuan berpikir kritis siswa berdasarkan gender, serta tidak ada perbedaan hasil belajar yang signifikan antara siswa berdasarkan gender [14]. Teori lain juga menunjukkan bahwa tidak terdapat perbedaan yang signifikan dari kemampuan berpikir kritis pada siswa laki-laki dan perempuan [15].

Selanjutnya untuk kemampuan berpikir kritis dengan menggunakan soal jumping task materi perbandingan pada kelompok kemampuan awal matematika kategori sedang dan kategori rendah, hasilnya adalah TKBK siswa laki-laki berada pada satu tingkat dibawah siswa perempuan. Temuan dalam penelitian ini juga sesuai dengan teori yang menyatakan bahwa nilai perempuan lebih unggul dari nilai laki-laki dalam hal kemampuan berpikir kritis analisis. Perempuan juga dinilai lebih unggul dari laki-laki dalam kemampuan membuat kesimpulan, yang berarti perempuan lebih mampu mengidentifikasi unsur-unsur yang dibutuhkan untuk menarik kesimpulan, untuk menyusun hipotesis, untuk mempertimbangkan informasi yang relevan [16]. 


\section{KESIMPULAN}

Berdasarkan hasil analisis kemampuan berpikir kritis dengan menggunakan soal jumping task materi perbandingan, terlihat bahwa subjek siswa laki-laki maupun siswa perempuan dari kelompok kemampuan awal matematika kategori tinggi mampu mencapai TKBK 3 yaitu kritis. Siswa laki-laki dan perempuan pada tingkat ini dapat menyelesaikan permasalahan, dapat dilihat dari hasil pengerjaan yang hampir memenuhi semua indikator namun tidak memenuhi indikator mendalam pada konsep dan ide. Konsep yang digunakan sesuai yaitu menggunakan konsep perbandingan senilai dan perbandingan berbalik nilai namun terbatas pada sudut pandang sehingga hanya mampu mengerjakan menggunakan penyelesaian tunggal.

Kelompok kemampuan awal matematika kategori sedang untuk siswa laki-laki berada pada TKBK 1 yaitu kurang kritis sedangkan untuk siswa perempuan berada pada TKBK 2 yaitu cukup kritis. Perbedaan siswa laki-laki dan perempuan kategori sedang adalah ada pada siswa perempuan yang terbatas pada sudut pandang sehingga hanya mampu mengerjakan menggunakan penyelesaian tunggal, sedangkan siswa laki-laki pada kategori sedang hanya sampai pada indikator konsep dan ide yang jelas yaitu menggunakan konsep perbandingan senilai dan perbandingan berbalik nilai.

Kelompok kemampuan awal matematika kategori rendah untuk siswa laki-laki berada pada TKBK 0 yaitu tidak kritis sedangkan siswa perempuan berada pada TKBK 1 yaitu kurang kritis. Perbedaan siswa laki-laki dan perempuan kategori rendah adalah ada pada siswa perempuan yang menggunakan konsep yang sesuai yaitu menggunakan konsep perbandingan senilai dan perbandingan berbalik nilai sedangkan siswa laki-laki pada kategori rendah tidak memahami maksud soal, tidak dapat menyelesaikan permasalahan karena tidak ada indikator yang terpenuhi, dan tidak dapat menarik kesimpulan. Jika dilihat dari kelompok kemampuan awal matematika kategori tinggi, maka tidak ada perbedaan yang signifikan pada kemampuan berpikir kritis antara siswa laki-laki dan siswa perempuan. Akan tetapi jika dilihat dari kelompok kemampuan awal matematika kategori sedang dan kategori rendah, hasilnya adalah Tingkat Kemampuan Berpikir Kritis (TKBK) siswa laki-laki berada pada satu tingkat dibawah siswa perempuan.

\section{DAFTAR PUSTAKA}

[1] Junaidi. (2017). Analisis Kemampuan Berpikir Kritis Matematika Siswa dengan Menggunakan Graded Response Models di SMA Negeri 1 Sakti," Artikel Ilmiah Mahasiswa, 4(1), 14-25.

[2] Mukhlisuddin. (2016). Pengembangan Berpikir Kritis pada Siswa Melalui Pemberian Tugas dengan Tingkat Kesukaran Berjenjang. Edumatica, 6(2), 70-80.

[3] Nofrion. (2017). Peningkatan Aktivitas Belajar Siswa Melalui Penerapan Metode "Jumping Task" pada Pembelajaran Geografi. Jurnal Geografi, 9(1), 11-20.

[4] Sugiarto, Susanto, \& M. Irvan. (2018). An Analysis of Student's Metacognition Abality Through Jumping Task Strategy to Solve Geometry Problem. International Journal of Advanced Research (IJAR), 6(3), 1375-1381.

[5] Hobri. (2020). Lesson Study for Learning Community: Penerapan dan Riset dalam Pembelajaran Matematika, Yogyakarta: LaksBang PRESSindo.

[6] Saiful, Susanto, \& Hobri (2019). The Students' Metacognition Analysis through Jumping Task Based on Lesson Study for Learning Community. IOP Conf. Series: Journal of Physics, 1265(1), 1-8. 
[7] Dilla, S. C., Hidayat, W., \& Rohaeti, E. E. (2018). Faktor Gender dan Resiliensi dalam Pencapaian Kemampuan Berpikir Kreatif Matematis Siswa SMA. Journal of Medives, 2(1), 129-136.

[8] Mhlanga, M. T. (2017). Student's Critical Ability in Solving Mathematics Problem Based on Gender Differences. International Journal of Science Arts and Commerce, 2(1), 67-74.

[9] Elder, L. \& Paul, R. (2010). Critical Thinking Development: A Stage Theory With Implications for Instruction, Tomales CA: Foundation for Critical Thinking.

[10] A. W. Kurniasih, A. W. (2010). Penjenjangan Kemampuan Berpikir Kritis Mahasiswa Prodi Pendidikan Matematika FMIPA UNNES dalam Menyelesaikan Masalah Matematika. Prosiding Seminar Nasional Matematika dan Pendidikan Matematika, Yogyakarta.

[11] P. Sugiyono, P. (2011). Metodologi Penelitian Kuantitatif Kualitatif dan R\&D, Alfabeta.

[12] Rahmatillah, S., Hobri, \& Oktavianingtyas, E. (2017). Tingkat Kemampuan Berpikir Kritis Siswa dalam Menyelesaikan Soal Barisan dan Deret Aritmatika di SMAN 5 Jember. KadikmA, 8(2), 51-60.

[13] Yunita, N. W., Hobri, Oktavianingtyas, E., Sunardi, \& Yudianto, E. (2018). Analisis Kemampuan Berpikir Kritis Siswa Dalam Menyelesaikan Soal Aritmetika Sosial Dalam Pembelajaran Berbasis Lesson Study for Learning Community Ditinjau Dari Kecerdasan Logis Matematis. KadikmA, 9(3), 1-10.

[14] Sulistiyawati \& Andriani, C. (2017). Kemampuan Berpikir Kritis dan Hasil Belajar Biologi Berdasarkan Perbedaan Gender Siswa. WACANA AKADEMIKA: Majalah Ilmiah Kependidikan, 1(2), 127-142.

[15] Miswari, M., Silitonga, \& Fajriyah, F. (2020). Identifikasi Kemampuan Berpikir Kritis Siswa Kelas X IPA Ditinjau dari Indikator Kemampuan Berpikir Kritis dan Gender. Jurnal Pelita Pendidikan, 8(1), 110-117.

[16] Cahyono, B. (2017). Analisis Ketrampilan Berfikir Kritis dalam Memecahkan Masalah Ditinjau Perbedaan Gender. AKSIOMA: Jurnal Matematika dan Pendidikan Matematika, 8(1), 50-64. 